\title{
Effect of some heavy metals on physiological and chemical parameters in Nile tilapia
} (Oreochromis niloticus L.)

\author{
Abdel-hakim N. F ${ }^{1}$, Helal A. $F^{1}$, Salem, M. $F^{2}$., Zaghloul A. $\mathbf{M}^{\mathbf{1}}$.and Hanbal M. $\mathbf{M}^{\mathbf{1}}$. \\ 1- Department of Animal Production, Faculty of Agriculture, Al-Azhar University. \\ 2- Central Laboratory for Aquaculture Research, \\ Abbassa, SharkiaSakha Aquaculture Research Unit.
}

\begin{abstract}
An experiment of 90 days was performed to study the effect of two sublethal levels of copper $(\mathrm{Cu})(0.25,0.125 \mathrm{ppm})$, mercury $(\mathrm{Hg})(0.01,0.005 \mathrm{ppm})$, lead $(\mathrm{Pb})(3,1.5 \mathrm{ppm})$ and cadmium $(\mathrm{Cd})(2,1 \mathrm{ppm})$ on growth performance, body composition and residual concentration of the Nile tilapia (Oreochromis niloticus). A set of 324 fish with $17 \mathrm{~g}$ average initial weight were divided into 36 similar groups in glass aquaria containing 90 liter of water in each. Treatments and control were allocated to the experimental groups in triplicates (3 groups / treatment). The fish were fed on commercial diet containing about $30 \%$ crude protein at a rate of $3 \%$ of the body weight daily during the experimental period. The results showed that, $\mathrm{Cu}, \mathrm{Hg}, \mathrm{Pb}$ and $\mathrm{Cd}$ caused a significant reduction in average weight gain (AWG), specific growth rate (SGR), and survival rate (SR) of Nile tilapia at the two levels studied as compared with the control. Feed conversion ratio (FCR) and protein efficiency ratio (PER) were the worst in groups exposed to the high levels of the investigated 4 heavy metals. On the other hand, the sublethal levels of $\mathrm{Cu}, \mathrm{Hg}, \mathrm{Pb}$ and $\mathrm{Cd}$ decreased crude protein (CP), and increased ether extract (EE) and ash in the body of Nile tilapia. Residues of the investigated heavy metals were higher in fish groups treated with them and their concentrations increased with increasing the level of heavy metal. The highest level of residues was found in the liver and kidney of fish groups treated with the high level of the investigated heavy metals.
\end{abstract}

Key words : Fish, heavy metals, $\mathrm{Cu}, \mathrm{Hg}, \mathrm{Pb}, \mathrm{Cd}$, growth, residues.

\section{INTRODUCTION}

Fish constitute an important source of protein for many people throughout the world and fish consumption has increased in importance among health-conscious people because it provides healthy and low cholesterol, sources of protein and other nutrients (Burger and Gechfeld, 2005; Agusa et al., 2005). Aquaculture is the main source of fish production in Egypt and it contributes about $61 \%$ of the total production (GAFRD, 2006). One of the main targets of the Egyptian government is to compensate the deficiency in meat production by increasing high quality fish production. Nile tilapia is by far the most important farmed tilapia species in the world. Tilapia is the most familiar and popular fishes in Egypt, as well as, in the Middle East and warm climate countries (Philippart and Ruwet, 1982). Fish production should be increased in Egypt to meet the demand of the increasing population. Several problems face fish production in Egypt. Among these problems are the mortality of fish due to low water quality because of pollution with heavy metal. Among environmental pollutants, metals are of particular concern, due to their potential toxic effect and ability to bioaccumulate in aquatic ecosystems (Censi et al., 2006 and Ekeanyanwu, 2010). Fish cannot escape from the detrimental effects of these pollutants (Olaifa et al., 2004). The heavy metals lead $(\mathrm{Pb})$, mercury ( $\mathrm{Hg})$, cadmium $(\mathrm{Cd})$, 


\section{Abdel-hakim N. F. et al.}

chrome $(\mathrm{Cr})$, arsenic (As), manganese $(\mathrm{Mg})$, nickel $(\mathrm{Ni})$, zinc $(\mathrm{Zn})$ and iron $(\mathrm{Fe})$ are toxic contaminants accumulated by fish. Any of these heavy metals can destroy life when they concentrate in the body above acceptable levels. Heavy metals have the tendency to accumulate in various organs and muscle tissue of fish. The world Health Organization as well as the food and Agriculture Organization of the United Nations state that monitoring eight elements in fish $(\mathrm{Hg}, \mathrm{Cd}, \mathrm{Pb}, \mathrm{As}, \mathrm{Cu}, \mathrm{Zn}, \mathrm{Fe}, \mathrm{Sn})$ is obligatory and monitoring of others is suggested. Heavy metals are regarded as serious pollutants in the aquatic environment because of their environmental persistence and tendency to concentrate in aquatic organisms (Harte et al., 1991; Schüürmann and Markert, 1998). High concentrations of heavy metals in water, sediments, and organisms may result in serious ecological consequences. Most heavy metals released into the environment enter the aquatic phase as a result of direct input, atmospheric deposition and erosion due to rain (Veena et al., 1997). Therefore, aquatic animals are often exposed to elevated levelsof heavy metals (Kalay and Canl1, 2000; Farkas et al., 2000; Farkas et al., 2001).

Heavy metals may be directly absorbed by organisms but are also transferred from lower to higher trophic levels of the food chain. The high accumulation of heavy metals in these components can result in serious ecological changes. The studies carried out on various fishes have shown that these metals alter the physiological activities and biochemical parameters both in tissues and blood (Basa and Rani, 2003).

The toxic effects of heavy metals have been reviewed, including their bioaccumulation by several workers (Rani , 2000; Waqar, 2006 ).

Copper compounds are commonly used to treat some of fish diseases in addition to its role for maintaining the normal biological activity of many enzymes. Copper was found as a trace metal in the natural water at a very low concentration. High levels of copper in the water are toxic to fish.

Lead, the most toxic metal, is detectable in practically all phases of the inert environment and all biological systems, because it is toxic to most living things at high exposure levels. Lead is non- essential element and it is a bone-seeking element, it is processed along with calcium because of its chemical resemblance to calcium. However, tissues other than bone are considered to be storage sites for lead in fish (Sorensen, 1991).

Cadmium is one of the toxic heavy metals which widely used in many industries. Presence of Cadmium in water reduces the growth, spawning activity and survival rate (SR) of different species of fish (Liloyd and Albaster, 1980; Sastry and Subhodra, 1985; Wang, 1993). Cadmium and lead are non-essential metals, as they are toxic, even in trace amounts (Fernandes et al ., 2008).

For the normal metabolism of the fish, the essential metals must be taken up from water, food or sediment (Canli and Atli, 2003). These essential metals can also produce toxic effects when the metal intake is excessively elevated (Tuzen, 2003). The mercury is a naturally occurring heavy metal and a waste product of industries such as coal-burning power plants. Once mercury enters the water, it is consumed by microorganisms, which are eaten by small fish, and these, in turn by bigger fish.

Therefore, the main objectives of the present study was to study the effect of heavy metals on the growth performance and feed utilization of Nile tilapia (Oreochromis niloticus). Also, to investigate the effect of heavy metals on the carcass chemical composition of fish body and on the residues in different parts of fish body. 


\section{Effect of some heavy metals on physiological and chemical parameters in Nile tilapia (Oreochromis niloticus L.)}

\section{MATERIALS AND METHODS}

The present work was carried out at the Aquaculture Research Unite, Sakha, Kafr Elsheikh, Governorate, Egypt, during summer season 2014. The experimental system consisted of (27) glass aquarium $\left(80 \times 50 \times 60 \mathrm{~cm}^{3}\right)$ each aquarium was filled with (90 liter) water and was supplied with air pump for oxygen requirements. Dechlorinated tap water was used to change one third of the water in each aquarium every day. Water was aerated before use for about 24 hours to remove chlorine.

The experiments were conducted to study the effect of two sublethal levels of each of the heavy metals $\mathrm{Cu}, \mathrm{Hg}, \mathrm{Pb}$ and $\mathrm{Cd}$. These investigated levels were $0.25,0.125 \mathrm{ppm}$ for $\mathrm{Cu} ; 0.01$, $0.005 \mathrm{ppm}$ for $\mathrm{Hg}$; 3, $1.5 \mathrm{ppm}$ for $\mathrm{Pb}$ and 2,1 ppm for $\mathrm{Cd}$. Their impacts were studied on growth performance, feed utilization, body chemical composition, residues in the different parts of fish body and relative organs weights, in Nile tilapia ( $O$. niloticus).

\section{1-Experimental fish:}

A group of 324 of Nile tilapia (O. niloticus) with average initial body weights of (17 gm). Fish were obtained from the stock of EL-Reyad fish farm (earthen pond) and transported to the aquarium located in the fish laboratory, Agriculture Research Center in Sakha. They were maintained in these aquariums for one month before the beginning of the experiment for acclimatization purpose. The fish were fed during the acclimatization period on an artificial basal diet at a rate of $3 \%$ of the body weight daily. The fish in experiment were distributed into the aquarium at 12 fish per aquarium; the experimental treatments were tested in three aquariums for each.

\section{2-Experimental diets:}

A basal diet (30\%) was formulated from the commercial ingredients (Fish meal, Soybean meal, yellow corn, wheat bran, mineral and vitamins mixture, and sunflower oil). The ingredients were bought from the local market, while vitamins and mineral mixture were obtained from (VICTOIR). Cairo, Egypt. Fish were fed during the acclimatization period on an artificial diet at a rate of $3 \%$ of the body weight daily. The composition and chemical analysis of ingredient diet and basal diet are presented in Tables $(1,2 \& 3)$, respectively.

Table (1). Composition and Chemical analysis of the ingredient diet.

\begin{tabular}{|c|l|c|c|c|c|c|c|}
$\begin{array}{r}\text { Chemical } \\
\text { analysis } \\
\text { Ingredients }\end{array}$ & $\begin{array}{l}\text { Dry } \\
\text { matter\% }\end{array}$ & $\begin{array}{l}\text { Crude } \\
\text { Protein \% }\end{array}$ & $\begin{array}{l}\text { Ether } \\
\text { extract \% }\end{array}$ & Ash \% & $\begin{array}{l}\text { Crude } \\
\text { Fiber \% }\end{array}$ & NFE \% & GEKcal/Kg \\
\hline Fish meal & 94.22 & 62.71 & 12.78 & 20.73 & 0.32 & 3.46 & 486.005 \\
\hline Soybean meal & 90.74 & 41.96 & 2.65 & 6.73 & 8.62 & 40.04 & 424.156 \\
\hline Yellow corn & 91.36 & 9.14 & 2.15 & 1.70 & 1.77 & 85.24 & 420.964 \\
\hline Wheat bran & 92.08 & 12.51 & 3.46 & 7.95 & 8.18 & 67.9 & 381.108 \\
\hline Sunflower oil & - & - & - & - & - & - & - \\
\hline Vit \& Min & - & - & - & - & - & - & - \\
\hline
\end{tabular}


Abdel-hakim N. F. et al.

Table (2). Composition of the control and experimental diet (On D.M basis).

\begin{tabular}{|l|l|}
\hline Ingredients & Diet \% \\
\hline Fish meal & $16 \%$ \\
Soybean meal & $38 \%$ \\
Yellow corn & $31 \%$ \\
Wheat brean & $10 \%$ \\
Sunflower oil & $4 \%$ \\
Vit \& Min & $1 \%$ \\
\hline Total & $100 \%$ \\
\hline
\end{tabular}

Table (3). Chemical analysis of experimental diet (\%).

\begin{tabular}{|l|l|}
\hline Analysis & \multicolumn{1}{|c|}{$\%$} \\
\hline Dry matter (DM \%) & $93.32 \%$ \\
Crude protein (CP \%) & $28.97 \%$ \\
Ether extract (EE \%) & $7.23 \%$ \\
Ash & $8.67 \%$ \\
Crude fiber (CF \%) & $3.95 \%$ \\
Nitrogen free & $51.18 \%$ \\
extract(NFE) $^{2}$ Gross & 380.32 \\
energy(GE) Kcal/Kg & \\
\hline
\end{tabular}

1. mineral premix g/Kg ( premix ) : (Vitamin A/1200000 IU, Vitamin D3/300000 IU, Vitamin E/700 mg, Vitamin B1/500 mg, Vitamin B2/200 mg, Vitamin B6/600 mg, Vitamin B12/3000 mg, Vitamin K3/500 mg, Vitamin C/450 $\mathrm{mg}$, Nicotinamide/3000 mg, Methionine/3000 mg, Choline Chloride/1000 mg, Folic Acid/300 mg, Calcium Pantonenate/670 mg, Biotine/600 mg, Mg Sulfate/3000 mg, Cu Sulfate/3000 mg, Fe Salfate/10000 mg, Zn Salfate/180 mg, Co Salfate/300 mg).

${ }^{2}$ - nitrogen free extract (NFE) was calculated as: $100-\%$ (Protein + Lipid + Ash + Crude fiber).

3 - gross energy (GE) calculated using the values 4.1, 5.6 and 9.44 Kcal GE/g DM of carbohydrate, protein and fat, respectively (NRC, 2012).

\section{3-Experimental treatments:}

On the basis of $\mathrm{LC}_{50}$ test, which was conducted before starting the experiment, according to (Weil, 1952), two sublethal levels of $\mathrm{Cu}(0.25,0.125 \mathrm{ppm}), \mathrm{Hg}(0.01,0.005 \mathrm{ppm}), \mathrm{Pb}(3,1.5$ $\mathrm{ppm})$ and $\mathrm{Cd}(2,1 \mathrm{ppm})$ were selected to study their effect on the growth performance, feed utilization, chemical composition and residues in fish body of $O$. niloticus. Fish were divided into (9) similar groups with (36) Fish.The treatments were randomly distributed on the experimental groups in three replicate (3 groups / treatments). Detailed data concerning the experimental design and treatment distribution are presented in Table (4). 
Effect of some heavy metals on physiological and chemical parameters in Nile tilapia (Oreochromis niloticus L.)

Table (4). Data concerning the experimental design and treatments distribution.

\begin{tabular}{|c|c|c|c|c|}
\hline $\begin{array}{c}\text { Treatments } \\
\text { number }\end{array}$ & $\begin{array}{c}\text { Heavy } \\
\text { metals }\end{array}$ & $\begin{array}{c}\text { Concentration } \\
\text { ppm }\end{array}$ & $\begin{array}{c}\text { Number of replicate } \\
\text { per treatment }\end{array}$ & $\begin{array}{c}\text { Number of fish per } \\
\text { aquarium }\end{array}$ \\
\hline $\mathrm{T} 1$ & $\mathrm{Control}$ & - & 3 & 12 \\
\hline $\mathrm{T} 2$ & $\mathrm{Cu} 1$ & 0.25 & 3 & 12 \\
\hline $\mathrm{T} 3$ & $\mathrm{Cu} 2$ & 0.125 & 3 & 12 \\
\hline $\mathrm{T} 4$ & $\mathrm{Hg} 1$ & 0.01 & 3 & 12 \\
\hline $\mathrm{T} 5$ & $\mathrm{Hg} 2$ & 0.005 & 3 & 12 \\
\hline $\mathrm{T} 6$ & $\mathrm{~Pb} 1$ & 3 & 3 & 12 \\
\hline $\mathrm{T} 7$ & $\mathrm{~Pb} 2$ & 1.5 & 3 & 12 \\
\hline $\mathrm{T} 8$ & $\mathrm{Cd} 1$ & 2 & 3 & 12 \\
\hline $\mathrm{T} 9$ & $\mathrm{Cd} 2$ & 1 & 3 & \\
\hline
\end{tabular}

\section{4-Experimental procedure:}

The experiment extended for 90 days. During the experimental period fish were fed daily on diets as shown in Table (3) at a rate $3 \%$ of body weight. The diet was introduced twice daily at 8 A.M. and 3 P.M. Quantity of feed was adjusted weekly based on actual body weight obtained on weekly basis. Samples of water were taken weekly from each aquarium to determine water quality parameters. At the end of the experiment, samples of fish were derived from each group, dried on $60{ }^{\circ} \mathrm{C}$ for 48 hours and then milled through electrical mill and kept at $4{ }^{\circ} \mathrm{C}$ until analysis.

\section{5-Proximate analysis of experimental diets and fish body:}

Determination of DM, CP, EE, CF and Ash of the basal diet and fish body of different experimental groups were carried out according to the methods of A.O.A.C (1990). The total tissue residue of heavy metals was estimated by Atomic Absorption Spectrophotometer following the method described by Stephen (1977).

\section{6-Analytical methods:}

\section{1-water quality analysis:}

Samples of water from each aquarium were taken to determine the physic-chemical characteristics of water. Determination of water parameters were measured as follows:

\section{a- Temperature:}

Water temperature in degree centigrade was recorded every day using thermometer.

\section{b-pH value :}

It was measured daily using electric digital $\mathrm{pH}$ meter, $\mathrm{pH} / \mathrm{MV} /$ Temperature meter EXTECH Instruments.

\section{c-Dissolved oxygen:}

It was determined using a dissolved oxygen meter EXTECH Instruments. 
Abdel-hakim N. F. et al.

d-Heavy metal concentrations in aquariums and residues in fish body:

These were determined using in Atomic Absorption Spectrophotometer (Varian/AA240FS) following the method described by Stephen (1977).

\section{7-Growth Parameters :}

The growth performance and feed utilization parameters were calculated according to the following equations:

-Total weight gain $($ TWG) in $\mathbf{g}=$ final weight $(\mathrm{g})$ - initial weight $(\mathrm{g})$

-Average daily gain (ADG) in $\mathbf{g}=\mathrm{TWG}(\mathrm{g}) / \mathrm{Time}$ (days)

-Survival rate $($ SR \% $)=$ Total number of fish at the end of the experimental $\times 100 /$ total number of fish at the start of the experiment.

-Specific growth rate $(\mathbf{S G R}, \% /$ day $)=100 \times[$ In wt1 - In wt0/T]

whereas:

In: Natural log, Wt1: Final weight $(\mathrm{g})$, Wt0: Initial weight $(\mathrm{g}), \mathrm{T}$ : Time in days

-Feed conversion ratio $(\mathbf{F C R})=$ Total feed consumption $(\mathrm{g}) /$ Weight gain $(\mathrm{g})$

-Protein efficiency ratio $(\mathbf{P E R})=$ Body weight gain $(\mathrm{g}) /$ protein intake $(\mathrm{g})$

\section{8- Statistical analysis:}

These were carried out by using SAS (2001) and Duncan (1955). Numerical data collected were statistically analyzed for analysis of variance and least significant difference $(\mathrm{P} \leq$ $0.05)$.

\section{1- Water quality parameters:}

\section{RESULTS AND DISSCUSION}

The most important physico-chemical parameters of tap water (experiment water) used in the experiment are shown in Table (5). All the environmental variables during the study were within the range considered suitable for the culture of Nile tilapia.

Table (5). Some measured water physico-chemical parameters.

\begin{tabular}{|c|c|c|c|c|c|c|c|}
\hline $\begin{array}{c}\text { Parameters } \\
\text { Treatments }\end{array}$ & $\begin{array}{c}\text { Temp. } \\
\text { oC }\end{array}$ & $\begin{array}{c}\text { DO } \\
\mathbf{m g} / \mathbf{L}\end{array}$ & $\mathbf{p H}$ & $\begin{array}{c}\mathbf{N H}_{\mathbf{3}} \\
\mathbf{m g} / \mathbf{L}\end{array}$ & $\begin{array}{c}\mathbf{T D S} \\
\mathbf{m g} / \mathbf{L}\end{array}$ & $\begin{array}{c}\mathbf{N O}_{\mathbf{2}} \\
\mathbf{m g} / \mathbf{L}\end{array}$ & $\begin{array}{c}\mathbf{N O}_{\mathbf{3}} \\
\mathbf{m g} / \mathbf{L}\end{array}$ \\
\hline T1 & 26.5 & 5.6 & 8.04 & 0.02 & 311 & 0.3 & 7.5 \\
\hline T2 & 26.2 & 5 & 8.13 & 0.03 & 321 & 0.5 & 16 \\
\hline T3 & 26.3 & 5 & 8.13 & 0.03 & 316 & 0.4 & 13 \\
\hline T4 & 26.3 & 4.6 & 8.14 & 0.03 & 318 & 0.4 & 14 \\
\hline T5 & 26.1 & 4.3 & 8.13 & 0.03 & 313 & 0.4 & 14 \\
\hline T6 & 26.2 & 4.4 & 8.25 & 0.05 & 332 & 0.8 & 20 \\
\hline T7 & 26.2 & 4.5 & 8.22 & 0.04 & 328 & 0.6 & 18 \\
\hline T8 & 26.1 & 4.2 & 8.23 & 0.06 & 327 & 0.9 & 23 \\
\hline T9 & 26.2 & 4.3 & 8.21 & 0.04 & 324 & 0.6 & 19 \\
\hline
\end{tabular}

$\mathrm{T} 1=($ control + without heavy metals $), \mathrm{T} 2=($ water $+\mathrm{Cu} 1), \mathrm{T} 3=($ water $+\mathrm{Cu} 2), \mathrm{T} 4=($ water $+\mathrm{Hg} 1)$, $\mathrm{T} 5=($ water $+\mathrm{Hg} 2), \mathrm{T} 6=($ water $+\mathrm{Pb} 1), \mathrm{T} 7=($ water $+\mathrm{Pb} 2), \mathrm{T} 8=($ water $+\mathrm{Cd} 1), \mathrm{T} 9=($ water $+\mathrm{Cd} 2)$. 


\section{Effect of some heavy metals on physiological and chemical parameters in Nile tilapia (Oreochromis niloticus L.)}

A temperature in water of all treatments was in optimal condition for fish culture which ranged from $26.1-26.3{ }^{\circ} \mathrm{C}$ (Table 5). Tekelioglu (1998) recommended a preferred temperature value for Tilapia between 20 to $35^{\circ} \mathrm{C}$. Dissolved oxygen remained within the recommended range for growth of Tilapia by aerating water to keep D.O average above $(4.1-5.5 \mathrm{mg} / \mathrm{l})$ as reported by many researchers (El - sayed, 2006; Bergheim et al., 2000).

The $\mathrm{pH}$ value of water was kept within the recommended range for growth of Nile tilapia (7.04 - 7.23) as recommended by Rijn et al. (2006) and Ismaniza (2012).

Amonia (NH3), TDS, $\mathrm{NO}_{2}$ and $\mathrm{NO}_{3}$ in water experiment were optimal for fish culture which ranged from $(0.01-0.02 \mathrm{mg} / \mathrm{l}, 298-333 \mathrm{mg} / 1,0.01-0.02 \mathrm{Mg} / \mathrm{l}$, and $0.01-0.02 \mathrm{mg} / \mathrm{l}$, respectively) as recommended by Middelburg and Nieuwenhuize (2000).

\section{2- Effect of $\mathrm{Cu}, \mathrm{Hg}, \mathrm{Pb}$ and $\mathrm{Cd}$ on growth parameters of Nile tilapia:}

Data in Table (6) showed the impact of the investigated heavy metals on the growth performance parameters of tilapia as affected by the experimental treatments (T1 to T9). Data concerning total weight gain (TWG), average daily gain (ADG), specific growth rate (SGR), and survival rate are presented in Table (6).

Table (6): Total weight gain, average daily gain, specific growth rate, and survival rate of Nile tilapia fingerlings reared in aquaria for $(90)$ days under different concentration of $\mathrm{Cu}$,

\begin{tabular}{|c|c|c|c|c|c|c|}
\hline $\begin{array}{c}\text { Parameters } \\
\text { Treatments }\end{array}$ & IW (g) & FW (g) & TWG (g) & ADG (g) & SGR\% & SR\% \\
\hline T1 & $17.92 \pm 0.01$ & $41.05 \pm 0.22^{\mathrm{a}}$ & $23.13 \pm 0.21^{\mathrm{a}}$ & $0.25 \pm 0.19^{\mathrm{a}}$ & $0.92 \pm 0.02^{\mathrm{a}}$ & $100 \pm 0.00^{\mathrm{a}}$ \\
\hline T2 & $17.64 \pm 0.03$ & $32.01 \pm 0.51^{\mathrm{c}}$ & $14.37 \pm 0.47^{\mathrm{c}}$ & $0.15 \pm 0.49^{\mathrm{c}}$ & $0.65 \pm 0.01^{\mathrm{c}}$ & $79.16 \pm 2.40^{\mathrm{e}}$ \\
\hline T3 & $17.75 \pm 0.02$ & $33.30 \pm 0.17^{\mathrm{b}}$ & $15.54 \pm 0.17^{\mathrm{b}}$ & $0.17 \pm 0.15^{\mathrm{b}}$ & $0.69 \pm 0.04^{\mathrm{b}}$ & $95.83 \pm 2.30^{\mathrm{ab}}$ \\
\hline T4 & $17.91 \pm 0.04$ & $27.62 \pm 0.16^{\mathrm{e}}$ & $9.71 \pm 0.12^{\mathrm{e}}$ & $0.10 \pm 0.17^{\mathrm{e}}$ & $0.47 \pm 0.03^{\mathrm{e}}$ & $83.33 \pm 1.05^{\mathrm{de}}$ \\
\hline T5 & $17.80 \pm 0.01$ & $30.38 \pm 0.84^{\mathrm{d}}$ & $12.57 \pm 0.86^{\mathrm{d}}$ & $0.13 \pm 0.75^{\mathrm{d}}$ & $0.59 \pm 0.01^{\mathrm{d}}$ & $95.83 \pm 2.10^{\mathrm{ab}}$ \\
\hline T6 & $17.82 \pm 0.02$ & $27.25 \pm 0.15^{\mathrm{e}}$ & $9.43 \pm 0.12^{\mathrm{e}}$ & $0.10 \pm 0.10^{\mathrm{e}}$ & $0.46 \pm 0.02^{\mathrm{e}}$ & $87.49 \pm 2.35^{\mathrm{cd}}$ \\
\hline T7 & $17.73 \pm 0.03$ & $29.70 \pm 0.11^{\mathrm{d}}$ & $11.97 \pm 0.08^{\mathrm{d}}$ & $0.13 \pm 0.05^{\mathrm{d}}$ & $0.57 \pm 0.01^{\mathrm{d}}$ & $91.66 \pm 2.12^{\mathrm{bc}}$ \\
\hline T8 & $17.70 \pm 0.07$ & $26.63 \pm 0.06^{\mathrm{e}}$ & $8.92 \pm 0.04^{\mathrm{e}}$ & $0.09 \pm 0.09^{\mathrm{e}}$ & $0.45 \pm 0.03^{\mathrm{e}}$ & $66.66 \pm 1.03^{\mathrm{f}}$ \\
\hline T9 & $17.81 \pm 0.03$ & $27.29 \pm 0.02^{\mathrm{e}}$ & $9.47 \pm 0.06^{\mathrm{e}}$ & $0.10 \pm 0.04^{\mathrm{e}}$ & $0.47 \pm 0.01^{\mathrm{e}}$ & $83.33 \pm 1.50^{\mathrm{de}}$ \\
\hline
\end{tabular}

$\mathrm{Hg}, \mathrm{Pb}$, and Cd ( mean $\pm \mathrm{SE})$.

$\mathrm{a}, \mathrm{b}, \mathrm{c}, \mathrm{d}, \mathrm{e}$, and $\mathrm{f}$, means in the same column having different letters are significantly $(\mathrm{P} \leq 0.05)$ different.

The results revealed that $\mathrm{Cu}, \mathrm{Hg}, \mathrm{Pb}$, and $\mathrm{Cd}$ caused significantly reduced growth, and survival rate at the investigated concentrations $(\mathrm{P} \leq 0.05)$. The total weight gain, and survival rate at the end of the experimental period were 23.13, 14.37, 15.54, 9.71, 12.57, 9.43, 11.97, 8.92, and 9.47g/fish for T1, T2, T3, T4, T5, T6, T7, T8 and T9, respectively. There were significant differences in TWG, ADG, SGR, and SR between the control and each of the other treated groups. However, there were not significant differences $(\mathrm{P} \geq 0.05)$ on $\mathrm{TWG}, \mathrm{ADG}, \mathrm{SGR}$, and $\mathrm{SR}$ between both levels of each of the investigated heavy metals. ADG, and SGR was the highest in the control group and differ significantly $(\mathrm{P} \leq 0.05)$ from all other groups. Survival rates were low in all fish groups treated with $\mathrm{Cu}, \mathrm{Hg}, \mathrm{Pb}$ and $\mathrm{Cd}$. The present results were in agreement with 
those found by several workers. Mahmoud (1997) and Mckim and Benoit (1971) observed a noticed decrease in production, and survival rate in trout, when treated with $\mathrm{Cu}, \mathrm{Hg}, \mathrm{Pb}$, and $\mathrm{Cd}$ at a level 0.25, 0.50, 0.50, and $0.1 \mathrm{ppb}$, respectively. Also, Stiff (1971) reported an adverse effect of $\mathrm{Cu}, \mathrm{Cd}$ and $\mathrm{Pb}$ at $0.25,0.1$ and $50 \mathrm{ppb}$, respectively.

Draz et al. (1993) recorded a significant decrease in final body weight and length of Nile tilapia treated with $0.25 \mathrm{ppm}$ copper sulphate. The results of this study were also similar to those found by Mahmoud (1997) and Hutchinson and Sprague (1985) who noticed a reduction in growth performance and survival rate of tilapia exposed to 1.1 to $29.5 \mathrm{ppb}$ of copper and cadmium, respectively.

Data in the literature obtained by many authors working on different species of fish revealed that cadmium had a negative effect on growth, survival, egg development of rainbow trout (Liloyd and Alabaster, 1980), on growth of catfish (Sastry and Subhodra, 1985) and on body weight of tilapia (Wang, 1993). On the Contrary, the present results were in disagreement with those found by other researchers, who found no effect of copper on body weight of sunfish (Causert, 1962), growth performance of yellow perch (John and Frank, 1974), growth and reproduction of fathead minnows (Mount and Stephan, 1967). Eaton (1974) also did not observe any adverse effect of cadmium chloride at $90 \mathrm{ppb}$ on growth or survival of blue gill.

The differences between the present results and the those of some workers on the effect of copper, mercury, lead, and cadmium may be due to the differences in their concentration used in the present study and other ones and to the differences among fish species. The negative effect of copper, mercury, lead, and cadmium on growth of tilapia species could be explained by the decreased cell division rate in fish group treated with these heavy metals (Mahmoud, 1997). The reduction in growth may also be attributed to the effect of the investigated heavy metals on the enzyme activities and metabolic processes.

\section{3- Effect of $\mathrm{Cu}, \mathrm{Hg}, \mathrm{Pb}$, and $\mathrm{Cd}$ on feed efficiency and protein utilization of Nile tilapia:}

Feed and protein utilization expressed as feed intake (FI), protein intake (PI), feed conversion ratio (FCR), protein efficiency ratio (PER), and relative growth rate for $O$. niloticus are given in table (7).

Table (7). Effect of concentration of $\mathrm{Cu}, \mathrm{Hg}, \mathrm{Pb}$, and $\mathrm{Cd}$ on feed efficiency and protein utilization in Nile tilapia.

\begin{tabular}{|c|c|c|c|c|c|}
\hline $\begin{array}{c}\text { Parameters } \\
\text { Treatments }\end{array}$ & FI (g) & PI (g) & FCR & PER & RGR\% \\
\hline T1 & $51.35 \pm 0.54^{\mathrm{a}}$ & $14.87 \pm 0.15^{\mathrm{a}}$ & $2.21 \pm 0.03^{\mathrm{e}}$ & $1.55 \pm 0.01^{\mathrm{a}}$ & $129.09 \pm 1.09^{\mathrm{a}}$ \\
\hline T2 & $44.63 \pm 0.40^{\mathrm{c}}$ & $12.92 \pm 0.11^{\mathrm{c}}$ & $3.10 \pm 0.07^{\mathrm{d}}$ & $1.10 \pm 0.02^{\mathrm{b}}$ & $81.46 \pm 2.54^{\mathrm{c}}$ \\
\hline T3 & $46.02 \pm 0.23^{\mathrm{b}}$ & $13.33 \pm 0.06^{\mathrm{b}}$ & $2.95 \pm 0.02^{\mathrm{d}}$ & $1.16 \pm 0.02^{\mathrm{b}}$ & $87.56 \pm 1.00^{\mathrm{b}}$ \\
\hline T4 & $39.90 \pm 0.11^{\mathrm{ef}}$ & $11.55 \pm 0.03^{\mathrm{ef}}$ & $4.10 \pm 0.04^{\mathrm{b}}$ & $0.83 \pm 0.04^{\mathrm{d}}$ & $54.20 \pm 0.58^{\mathrm{e}}$ \\
\hline T5 & $42.40 \pm 0.73^{\mathrm{d}}$ & $12.28 \pm 0.21^{\mathrm{d}}$ & $3.39 \pm 0.17^{\mathrm{c}}$ & $1.02 \pm 0.05^{\mathrm{c}}$ & $70.64 \pm 4.90^{\mathrm{d}}$ \\
\hline T6 & $40.07 \pm 0.51^{\mathrm{e}}$ & $11.60 \pm 0.14^{\mathrm{e}}$ & $4.24 \pm 0.02^{\mathrm{ab}}$ & $0.81 \pm 0.02^{\mathrm{d}}$ & $52.92 \pm 0.64^{\mathrm{e}}$ \\
\hline T7 & $42.06 \pm 0.17^{\mathrm{d}}$ & $12.18 \pm 0.05^{\mathrm{d}}$ & $3.51 \pm 0.01^{\mathrm{c}}$ & $0.97 \pm 0.02^{\mathrm{c}}$ & $67.52 \pm 0.34^{\mathrm{d}}$ \\
\hline T8 & $38.81 \pm 0.09^{\mathrm{f}}$ & $11.23 \pm 0.02^{\mathrm{f}}$ & $4.34 \pm 0.01^{\mathrm{a}}$ & $0.79 \pm 0.03^{\mathrm{d}}$ & $50.42 \pm 0.22^{\mathrm{e}}$ \\
\hline T9 & $39.48 \pm 0.03^{\text {ef }}$ & $11.43 \pm 0.01^{\text {ef }}$ & $4.16 \pm 0.02^{\text {ab }}$ & $0.82 \pm 0.01^{\mathrm{d}}$ & $53.19 \pm 0.45^{\mathrm{e}}$ \\
\hline
\end{tabular}

$\mathrm{a}, \mathrm{b}, \mathrm{c}, \mathrm{d}, \mathrm{e}$, and $\mathrm{f}$, mean in the same column having different letters are significantly $(\mathrm{P} \leq 0.05)$ different.

Results indicated that, FI, PI, FCR, PER, and RGR decreased in fish groups grown in $\mathrm{Cu}$, $\mathrm{Hg}, \mathrm{Pb}$, and $\mathrm{Cd}$ polluted water as compared with the untreated fish (control). The results showed 


\section{Effect of some heavy metals on physiological and chemical parameters in Nile tilapia (Oreochromis niloticus L.)}

that there was a significant decrease in food consumption during the period of the experiment. Abdel-Tawab and Wafeek (2008) carried out a study to evaluate the resistance of Nile tilapia, fed on organic selenium supplemented diet to water born cadmium toxicity, and they found that fish performance and all the biochemical aspects were affected significantly by the investigated concentrations of $\mathrm{Cd}$. Also, the present result was in agreement with that of Sunita and Gupta, (2015) who found a significant increase in food conversion ratio in all the heavy metal treated fishes $(\mathrm{P}=0.05)$. Ranjana et al. (2015) reported that, $\mathrm{Pb}$ is highly toxic, impairing biological functions of aquatic animals. Also, Sunita and Gupta (2015) reported that, water pollution with heavy metals affects various physiological processes in fish, usually causes depletion in food utilization in fish and such disturbance may result in reduced fish metabolic rate.

\section{4- Chemical composition of body fish:}

Values of dry mater (DM), crude protein (CP), ether extract (EE) and ash in the body of Nile tilapia was summarized in Table (8).

Table (8). Effect of $\mathrm{Cu}, \mathrm{Hg}, \mathrm{Pb}$, and $\mathrm{Cd}$ on the chemical composition of Nile tilapia.

\begin{tabular}{|c|c|c|c|c|}
\hline Treatments & $\begin{array}{c}\text { Dry matter } \\
\%\end{array}$ & $\begin{array}{c}\text { Crude Protein } \\
\%\end{array}$ & $\begin{array}{c}\text { Ether extract } \\
\%\end{array}$ & $\begin{array}{c}\text { Ash } \\
\%\end{array}$ \\
\hline Initial & $22.05 \pm 0.01^{\mathrm{f}}$ & $43.61 \pm 0.02^{\mathrm{g}}$ & $3.70 \pm 0.11^{\mathrm{f}}$ & $14.54 \pm 0.24^{\mathrm{f}}$ \\
\hline $\mathrm{T} 1$ & $25.50 \pm 0.54^{b c}$ & $58.67 \pm 0.54^{\mathrm{a}}$ & $4.69 \pm 0.17^{\mathrm{ef}}$ & $19.50 \pm 0.57^{\mathrm{e}}$ \\
\hline $\mathrm{T} 2$ & $28.35 \pm 0.92^{\mathrm{a}}$ & $52.63 \pm 0.70^{\mathrm{de}}$ & $14.09 \pm 0.83^{\mathrm{a}}$ & $20.56 \pm 0.81^{\mathrm{de}}$ \\
\hline T3 & $26.21 \pm 0.45^{b}$ & $54.75 \pm 0.34^{\mathrm{bc}}$ & $9.96 \pm 0.74^{\mathrm{c}}$ & $22.08 \pm 0.60^{\mathrm{cd}}$ \\
\hline $\mathrm{T} 4$ & $24.54 \pm 0.38^{\mathrm{bcd}}$ & $51.97 \pm 0.51^{\mathrm{e}}$ & $10.08 \pm 0.81^{\mathrm{c}}$ & $20.44 \pm 0.58^{\mathrm{de}}$ \\
\hline T5 & $23.51 \pm 0.30^{\text {def }}$ & $53.60 \pm 0.26^{\mathrm{cd}}$ & $7.26 \pm 0.25^{\mathrm{d}}$ & $23.68 \pm 0.48^{b c}$ \\
\hline T6 & $24 \pm 0.84^{\text {cde }}$ & $53.54 \pm 0.24^{\mathrm{cd}}$ & $12.16 \pm 0.15^{\mathrm{b}}$ & $20.10 \pm 0.49^{\mathrm{e}}$ \\
\hline $\mathrm{T} 7$ & $23.39 \pm 0.64^{\text {def }}$ & $55.24 \pm 0.24^{b}$ & $9.44 \pm 0.71^{\mathrm{c}}$ & $27.12 \pm 0.93^{\mathrm{a}}$ \\
\hline T8 & $22.57 \pm 0.35^{\text {ef }}$ & $48.68 \pm 0.30^{\mathrm{f}}$ & $11.21 \pm 1.09^{\mathrm{bc}}$ & $20.22 \pm 0.08^{\mathrm{de}}$ \\
\hline T9 & $22.21 \pm 0.27^{f}$ & $51.78 \pm 0.25^{\mathrm{e}}$ & $6.50 \pm 0.43^{\mathrm{de}}$ & $25.10 \pm 0.60^{b}$ \\
\hline
\end{tabular}

$\mathrm{a}, \mathrm{b}, \mathrm{c}, \mathrm{d}, \mathrm{e}, \mathrm{f}$, and $\mathrm{g}$, mean in the same column having different letters are significantly $(\mathrm{P} \leq 0.05)$ different.

The results showed that, control groups of Nile tilapia had the highest crude protein $(\mathrm{CP})$ values and the lowest ether extract (EE) and ash percentage. The percentages of (CP) decreased as the level of the investigated metal increased, while the values of (EE) and ash increased with increasing levels of these heavy metals. Yet, the negative effects of the studied heavy metals may be due to decreased immunity and feed utilization in fish body. These results were in agreement with those reported by Noaman et al. (1992) and Mahmoud (1997) who found that, crude protein content decreased in $\mathrm{O}$. niloticus grown in water polluted with $\mathrm{Cd}$ and $\mathrm{Cu}$ as compared with untreated fish, while lipids decreased as the level of each heavy metal decreased. Sastry and Gupta (1979) found that, protein decreased when fish were exposed to cadmium chloride at 6.8 ppm, which was in agreement with the present results. Abdel-hamid and El- Ayouty (1991) studied the composition of Clarias lazera reared in water contaminated with lead or aluminum compounds at levels of 10,50, and 100ppm of each. They found that ether extract was increased as the lead chloride levels increased. On the other hand, crude protein of contaminated fish was 
Abdel-hakim N. F. et al.

somewhat less than that of the control and decreased by increasing the level of lead. Ash contents were decreased in all levels than that of the control.The result obtained in this study dealt with ash content were similar to that reported by Mahmoud (1997) and Noaman et al., (1992) which indicated that content of heavy metal in water environment, positively correlated with ash content in fish parts. Data obtained in the present study suggest that heavy metals may stimulate lipid deposition in the body of tilapia on the account of protein. Some workers found a similar trend as was showed previously, but others reported different results, where they found that protein increased in heavy metal treated fish groups (Khadre 1990; Hassan, 1964; Merlini, 1978). Monam and Mohamed (1994) recorded an increase in the level of protein and lipids when the Nile catfish were exposed to copper chloride at a level of $0.01 \mathrm{ppm}$ for $24 \mathrm{hr}$. Ali et al., (2003) reported that the body moisture and ash contents were the highest $(\mathrm{P}<0.05)$ whereas the fat and gross energy contents were the lowest $(\mathrm{P}<0.05)$ in fish reared in water containing 0.5 ppm of copper as compared with others. No significant $(\mathrm{P}<0.05)$ differences were observed in the whole body crude protein content of fish exposed to different concentrations of copper as compared with the control. Liver moisture and ash contents increased $(\mathrm{P}<0.05)$ whereas the crude protein, fat, nitrogen free extract and gross energy contents decreased $(\mathrm{P}<0.05)$ when the fish were exposed to different concentrations of copper as compared with the control.

\section{5- Residues of heavy metals in the whole fish body:-}

The data concerning $\mathrm{Cu}, \mathrm{Hg}, \mathrm{Pb}$, and $\mathrm{Cd}$ residues in the whole fish body were shown in Table (9). The concentration of the investigated heavy metals in the control fish were as follow:

$\mathrm{Cu}$ in liver $30.75 \mathrm{mg} / \mathrm{Kg}$, kidney $22.90 \mathrm{mg} / \mathrm{Kg}$, gills $3.15 \mathrm{mg} / \mathrm{Kg}$, and muscles 1.75 $\mathrm{mg} / \mathrm{Kg}$. However, $\mathrm{Hg}, \mathrm{Pb}$, and $\mathrm{Cd}$ were not recorded in liver, kidney, gills, and muscles of control fish.

Table (9): The heavy metals $(\mathrm{Cu}, \mathrm{Hg}, \mathrm{Pb}$, and $\mathrm{Cd})$ residues in the whole fish body.

\begin{tabular}{|c|c|c|c|c|c|}
\hline Treatment & Replicate & $\begin{array}{c}\text { Liver } \\
\mathbf{m g} / \mathbf{K g}\end{array}$ & $\begin{array}{c}\text { Kidney } \\
\mathbf{m g} / \mathbf{K g}\end{array}$ & $\begin{array}{c}\text { Gills } \\
\mathbf{~ m g / K g}\end{array}$ & $\begin{array}{c}\text { Muscles } \\
\mathbf{~ m g / K g}\end{array}$ \\
\hline \multirow{3}{*}{$\mathrm{T} 1$} & $\mathrm{Cu}$ & $30.75 \pm 0.89^{\mathrm{g}}$ & $22.90 \pm 1.61^{\mathrm{g}}$ & $3.15 \pm 0.25^{\mathrm{g}}$ & $0.94 \pm 0.09^{\mathrm{f}}$ \\
\cline { 2 - 6 } & $\mathrm{Hg}$ & $0.00 \pm 0.00^{\mathrm{h}}$ & $0.00 \pm 0.00^{\mathrm{g}}$ & $0.00 \pm 0.00^{\mathrm{g}}$ & $0.00 \pm 0.00^{\mathrm{g}}$ \\
\cline { 2 - 6 } & $\mathrm{Pb}$ & $0.21 \pm 0.01^{\mathrm{h}}$ & $0.08 \pm 0.02^{\mathrm{g}}$ & $0.05 \pm 0.02^{\mathrm{g}}$ & $0.00 \pm 0.00^{\mathrm{g}}$ \\
\cline { 2 - 6 } & $\mathrm{Cd}$ & $0.07 \pm 0.02^{\mathrm{h}}$ & $0.02 \pm 0.01^{\mathrm{g}}$ & $0.03 \pm 0.01^{\mathrm{g}}$ & $0.00 \pm 0.00^{\mathrm{g}}$ \\
\hline $\mathrm{T} 2$ & $\mathrm{Cu} 1$ & $424 \pm 14.89^{\mathrm{c}}$ & $545.33 \pm 19.77^{\mathrm{c}}$ & $21.65 \pm 0.60^{\mathrm{c}}$ & $6.65 \pm 0.08^{\mathrm{a}}$ \\
\hline $\mathrm{T} 3$ & $\mathrm{Cu} 2$ & $230.15 \pm 5.62^{\mathrm{d}}$ & $305 \pm 6.23^{\mathrm{e}}$ & $11.05 \pm 1.58^{\mathrm{f}}$ & $4.60 \pm 0.05^{\mathrm{bc}}$ \\
\hline $\mathrm{T} 4$ & $\mathrm{Hg} 1$ & $132.65 \pm 17.98^{\mathrm{e}}$ & $524.30 \pm 33.71^{\mathrm{c}}$ & $31.35 \pm 2.39^{\mathrm{b}}$ & $5.15 \pm 0.14^{\mathrm{b}}$ \\
\hline $\mathrm{T} 5$ & $\mathrm{Hg} 2$ & $55.05 \pm 6.49^{\mathrm{f}}$ & $319.10 \pm 12.70^{\mathrm{e}}$ & $17.40 \pm 1.15^{\mathrm{de}}$ & $2.75 \pm 0.08^{\mathrm{d}}$ \\
\hline $\mathrm{T} 6$ & $\mathrm{~Pb} 1$ & $1139.8 \pm 2.10^{\mathrm{a}}$ & $1787.2 \pm 6.29^{\mathrm{a}}$ & $108.20 \pm 0.63^{\mathrm{a}}$ & $4.35 \pm 0.54^{\mathrm{c}}$ \\
\hline $\mathrm{T} 7$ & $\mathrm{~Pb} 2$ & $1129.4 \pm 3.75^{\mathrm{a}}$ & $1451.2 \pm 15.84^{\mathrm{b}}$ & $105.90 \pm 0.17^{\mathrm{a}}$ & $1.75 \pm 0.25^{\mathrm{e}}$ \\
\hline $\mathrm{T} 8$ & $\mathrm{Cd} 1$ & $877.95 \pm 9.61^{\mathrm{b}}$ & $418.55 \pm 9.61^{\mathrm{d}}$ & $20.75 \pm 2.97^{\mathrm{cd}}$ & $1.17 \pm 0.12^{\mathrm{f}}$ \\
\hline $\mathrm{T} 9$ & $\mathrm{Cd} 2$ & $132.40 \pm 6.52^{\mathrm{e}}$ & $82.60 \pm 3.98^{\mathrm{f}}$ & $15.55 \pm 1.70^{\mathrm{e}}$ & $0.97 \pm 0.13^{\mathrm{f}}$ \\
\hline
\end{tabular}

$\mathrm{a}, \mathrm{b}, \mathrm{c}, \mathrm{d}, \mathrm{e}, \mathrm{f}, \mathrm{g}$, and $\mathrm{h}:$ mean in the same column having different letters are significantly $(\mathrm{P} \leq 0.05)$ different.

Based on values found in Table (9) it can be observed that, the highest metals residues were found in the liver, and kidney of the fish exposed to the highest levels of $\mathrm{Cu}, \mathrm{Hg}, \mathrm{Pb}$ and 


\section{Effect of some heavy metals on physiological and chemical parameters in Nile tilapia (Oreochromis niloticus L.)}

Cd, while the lowest values were observed in gills and muscles. Whereas, T2, T3, T4, T5, T6, T7, T8, and T9 reflected the highest level being 0.25, 0.125, 0.01, 0.005, 3, 1.5, 2, and $1 \mathrm{ppm}$, respectively. So, T1 was the best treatment in reducing the levels of the residues, in this respect.

The present results demonstrate that the concentration of heavy metals in fish liver, kidney, and gills is much higher than those in muscles. Similar results were obtained by Jobling (1995) and Ahmed et al. (2011). The results of this study were also similar to those found by Horowitz and Presley (1977) who studied the concentration of cadmium in some fish species in Gulf of Mexico; they found that the higher concentration of cadmium was $0.89 \mathrm{ppm}$ in liver and $0.15 \mathrm{ppm}$ in muscle.

Also, Bohn and Fallis (1978) recorded the concentration of cadmium levels in some species of fish in Canada and found that the levels were $4.10 \mathrm{ppm}$ and $1.40 \mathrm{ppm}$ in liver and muscles. Crespo et al. (1986) found that lead residues were concentrated in kidneys followed by liver in the Rainbow trout fed lead at concentration of $10 \mathrm{mg} \mathrm{Pb} / \mathrm{kg}$ per day for 15 days. Khallaf et al. (2003) studied the heavy metals concentrations in O. niloticus fish organs in a drainage canal, at El-menofeya province Egypt. They reported that the concentration of Cd in fish organs (mg/kg dry weight) were as follows, Kidney (19.2), liver (8.8), and musculature (4.9). On the Contrary, the present results were in disagreement with those found by other researchers, Mohamed (1991) determined the residues of heavy metals (cadmium, zinc and lead) in different tissue of Tilapia nilotica from Maryout lake. The result showed that zinc was the most abundant heavy metals in the brain, bone and muscles. Lead was always at levels exceeding those of cadmium.

\section{REFERENCES}

Abdelhamid, A.M. and El- Ayouty, S.A (1991). Effect on catfish (Clarias lazera) composition of ingestion rearing water contaminated with lead or aluminum compounds. Arch. Anim. Nutr. Berlin, 41 :757-763.

Abdel-Tawwab, M. and Wafeek, M. (2010). Response of Nile Tilapia, Oreochromis niloticus (L) to environmental cadmium toxicity during organic selenium supplementation. J.World Aquacult. Soc., 41: 106-114.

Agusa. T.; Kunto, G.; Yasunaga, H.; Iwata, A. and Tanabe, S. (2005). Concentrations of trace elements in marine fish and its risk assessment in Malaysia. Mar. Pollut. Bull., 51:896 911.

Ahmed, M.S.; Aslam, Y. and Khan, W.A. (2011). Absorption and bioaccumulation of waterborne inorganic mercury in the fingerlings of grass carp, Ctenopharyngo donidella: J. Animal and Plant Sci., 21 (2): 176-181.

Ali, S.M. Al-Ogaily; N.A. Al-Asgah and J. Gropp (2003). Effect of sublethal concentrations of copper on the growth performance of Oreochromis niloticus. J. Appl. Ichthyol., 19 : $183-188$.

A.O.A.C. (1990). Association of official analytical chemists. Official Methods of Analysis, $12^{\text {th }}$ Ed. Washingtion Dc.

Basa, S.; P. Usha and Rani, A. (2003). Cadmium induced antioxidant defense mechanism in freshwater teleost Oreochromis mossambicus (tilapia). EcoToxicology Environment Safety, 2(56): 218-221.

Bergheim, A.; Gausen, M. and Næss, A. (2002). Effects of oxygen deficit on post-molt salmon. Trial I. Report RF-2002/307. 25p. 


\section{Abdel-hakim N. F. et al.}

Bhon, A. and Fallis, B.W. (1978). Metal concentrations (As, Cd, Cu, Pb and $\mathrm{Zn}$ ) in short horn sculpins, Myoxo Cephalus scorpinus (Linnaeus) and Arctic char, Salvelinus alpinus (Linnaeus), from the vicinity of strathcona sound, North west territories.Water Res., 13:659.

Burger, J. and Gechfeld, M. (2005). Heavy metals in commercial fish in new Jersey. Environ. Res., 99:403- 412.

Canli, M. and Atli, G. (2003).The relationships between heavy metal (Cd, Cr, Cu, Fe, Pb, Zn) levels and the size of six Mediterranean fish species. Environ. Pollut., 121: 129-136.

Causert, J. (1962). Fish as a source of mineral nutrition. In : Borgestrom Fish as Food, 11:205-228.

Censi, P.; Spoto, S.E.; Saiano, F.; Sprovieri, M.; Mazzola, S.; Nardone, G.; Di Geronimo, S.I.; Punturo, R. and Ottonello, D. (2006). Heavy metals in coastal water systems. A case study from the northwestern Gulf of Thailand. Chemosphere, 64: 1167-1176.

Crespo, S.; Nonnotte, G.; Colin, D.A.; Lera, C.; Nonnotte, L. and Aubree, A. (1986). Morpological and functional alterations induced in trout intestine by dietary cadmium and lead. J. Fish Biol., 28: 69- 80.

Draz, A.A.; Samoha, I.A.; El-Telbany, M.M. and Sarha, A.I. (1993). Effects of chronic exposure to copper on production and total residues among tilapia species. Bull. Nat. Inst. Oceanogr. \& Fish ; A. R.E., 196 : 351- 362.

Duncan , D.B. (1955). Multiple range and multiple F-test. Biometrics, 11: 1-42 .

Eaton, J.G. (1974). Chronic cadmium toxicity to the bluegill (Lepomis macrochirus Rafinesque). TAFASI, $13: 729-730$.

Ekeanyanwu, C.R.; Ogbuinyi, C.A and Etienajirhevwe, O.F. (2010). Trace metals distribution in fish tissues, bottom sediments and water from Okumeshi River in Delta State, Nigeria. Ethiopian J. Environ. Stud. and Manag., 3(3):12-17.

El-sayed, A.F.M. (2006).Tilapia culture in salt water environmental requirement nutritional implications and economic potentials.Vlll symposium international de Nutrition Acuicola Universidad Autonoma de Nuevo lean Anais. Monterrey.

Farkas, A.; J. Salanki; A. Specziar and 1. Varanka (2001). Metal pollution as health indicator of lake ecosystems. Int. J. Occupational Medi. Environ. Health, 14 (2): 163-170

Frenandes, C.; Fontainhas-Fernandes, A.; Cabral, D. and Salgado, M.A. (2008). Heavy metals in water, sediments and tissues of Liza saliens from Esmoriz-Paramos lagoon, Portugal. Environ. Monit. Assess., 136: 267- 275.

GAFRD, General Authority for Fish Resources Development (2006). Fishery Annual Report, Cairo, Egypt.

Harte, J.; C. Holdren; R. Schneider and C. Shirley (1991). Toxics A to Z, A guide to everyday pollution hazards, University of California Press, Oxford, England, pp. 478,

Hassan, Y.M. (1964). Technological studies on some varieties of fish from Egyptian water. Ph.D Thesis Ain Shams Univ., Cairo Egypt.

Horowitz, A. and Presley, B.J. (1977). Trace metal concentrations and partitioning in Zooplankton, neuston, and benthos from south Texas outer continental shelf. Arch. Environ. Cont., 5:241.

Hutchinson, N.J. and Sprague, J.B. (1985). Toxicity of trace metal mixture to American Flag fish in salt, acidic water and implications for cultural acid cation. Com. J. Fish Aquat. Sci., 43: 646-655. 


\section{Effect of some heavy metals on physiological and chemical parameters in Nile tilapia (Oreochromis niloticus L.)}

Ismaniza, I. and Idaliza, M.S. (2012). Analysis of heavy metals in water and fish (Tilapia sp.) samples from tasikmutiara, puchong. Malaysian J. Analytical Sci., 16(3):346-352.

Jobling, M. (1995). Environmental Biology of fishes. I ${ }^{\text {st }}$ ed. printed in Great Britian. Chapman and Hall, London.

John, R.M. and Frank, R.B. (1974). Organochiorine residues, mercury, copper and cadmium in yellow perch, while bass and small mouth bass, longpont Bay, lake Erie. TAFSAI, 3:577-587.

Kalay, M. and Canli, M. (2000). Elimination of essential ( $\mathrm{Cu}$ and $\mathrm{Zn}$ ) and non essential (Cd and $\mathrm{Pb}$ ) metals from tissues of a fresh water fish, Tilapia zillii. Tropical J. Zool., 24:429-436.

Farkas, A.; J. Salanki and 1. Varanka (2000). Heavy metal concentrations in fish of lake Balaton. Lakes and Reservoirs: Res. Manag., 5: 271-279

Khadre, S.E. (1990). Cytological and cytochemical studies on the liver of Tilapia zillii surviving in Lake Maruit. Ecotox. Environ. Safe, 19:123-135.

Khallaf, E.A.; GalaI, M. and Authman, M. (2003). The biology of Oreochromis niloticus in a polluted canal. Ecotoxicology,12:405-416.

Liloyd, R. and Albaster, J.S. ( 1980). Water quality criteria for freehwater fish, I ${ }^{\text {st }}$ Ed. Food and Agriculture Organization of the United Nations Published by Butter Worths Fondan Boston.

Mahmoud, F.S. (2008). Effect of cadmium, copper and lead contamination on growth performance and chemical composition of Nile tilapia (Oreochromis niloticus). J. Agric . Sci. Mansoura Univ., 28(10): 7209-7222 .

Mahmoud, F.I.S. (1997). Effect of some heavy metals on growth performance and chromosomal behavior of some local tilapia species, Thesis MSC. Department of Animal Production. Faculty of Agriculture at Kafer El- Sheikh, Tanta Univ. Egypt 1997.

Mckim, J.M. and Benoit, D.A. (1971). Effect of long-term exposure to copper on survival, growth and reproduction of brook trout ( Salelinus fontinalis). J.Fish Res., Bd. Canada, 28:655-662.

Merlini, M. (1978). Hepatic storage alteration of protein, lipid and ash content by cadmium in fresh water fish. Bull. Environ.Contan. Toxical., 19:767-771.

Middelburg, J.J. and Nieuwenhuize, J. (2000). Nitrogen uptake by heterotrophic bacteria and phytoplankton in the nitrate-rich Thames estuary. Marine Ecology Progress Series, 203, 13-21.

Mohamed, I.G. (1991). Biochemical interaction between two insecticides and five heavy metals in two types of fish.Ph. D. Thesis, Fac. Agric., Alex. Univ.

Monam, E. and Mohamed, W. (1994). Some metabolic effects of cop, zinc and mercury pollution in Nile catfish. $2^{\text {nd }}$ Vet. Med. Cong. Zagazig. 11-13 October, 10-14.

Mount, D.I. and Stephan, C.E. (1967). A method for detecting cadmium poisoning in fish. J. Will. Mgm., 13 : 168-172.

Noaman, M.A. ; El-Sebaie, L.A. ; Kassab, H.E. and Atta, M.B. ( 1992).Chemical composition of raw and cooked bolti (Tilapia nilotcia) grown in water polluted with some heavy metals. Food Sei.\& Technol. Dept., Agric. Fac., kafr El-Sheikh, Tanta Univ., 10:185-193.

NRC (2012). Nutrition requirement of fish, Committee on Animal Nutrition, Board on Agriculture . National Academy press, Washington, DC . 


\section{Abdel-hakim N. F. et al.}

Olaifa, F.E.; Olaifa, A.K.; Adelaja, A.A. and Owolabi, A.G, (2004). Heavy metal contamination of Clarias gariepinus from a Lake and fish farm in Ibadan, Nigeria. Afr. J. Biomed. Res., 7: 145-148.

Philippart, J.C.L. and J.C.L. Ruwet (1982). Ecology and distribution of tilapias. In: R.H. LoweMc Connell (eds.). The Biology and Culture of Tilapia. International Center for living Aquatic Resources Management, Manila, Philippines: 15-59.

Rani, U.A. (2000). Cadmium induced bioaccumulation in tissue of freshwater teleost Oreochromis mossambicus. Ann. N.Y. Academy, 1(919): 318- 320.

Ranjana, S.; Mohini, G.; Ekhalak, A. (2015). Accumulation of lead in the muscle of brackish water fish (Boleopthalmusdussumieri). J. Appl. and Nat. Sci., 7(2):662-665.

Rijn, J.V.; Tal, Y. and Schreier, H.J. (2006). Denitrification in recirculating systems. Theory and application Aquac. Eng., 34(3): 364-376.

SAS (2001). SAS / STAT Guide for personal computer. SAS Inst. Cary, N.C .

Sastry, K.V. and Subhodra, K.M. (1985). Effects of cadmium on some enzyme activities in tissues of the fresh water catfish. Environ. Res., 36:32-45.

Sastry, K.V. and Subhodra, K.M. (1985). Effects of cadmium on some enzyme activities in tissues of the fresh water catfish. Environ. Res., 36:32-45.

Sastry, K.V. and Gupta, P.K. ( 1979). The effect of cadmium on the digestive system of teleost fish. Heteropneustes fossilis. Environ. Res., 19:221-230.

Schüürmann,G. and B. Markert (1998). Ecological fundamentals, chemical exposure, and biological effects, John Wiley \& Sons, lnc. and Spektrum Akademischer Verlag, pp. 900 .

Sorensen, E.M. (1991). Metal poisoning in fish: Environmental and Life Sciences Associates. Austin, Texas. CRC Press, Boca Raton, Florida. Species of Persian Gulf in Bushehr Port, Iran. Afr. J. Biotechnol., 9(37): 6191-6193.

Stephen, G.C. (1977). Metals and other elements, Atomic absorbtion spectrophotometer determination of lead, cadmium, zinc and copper in clams and oysters: collaborative study. J. A.O.A.C., 60: 1400-1407.

Stiff, M. J. (1971).The chemical states of copper in polluted fresh water and scheme of analysis to differentiate them.Wat. Res., 5: 585-599.

Sunita, R.; Gupta, R.K. (2015). Effect of heavy metals on the morphology and growth performance of Indian major carps. Annals of Biology, 31(1):117-121.

Tekelioglu, N. (1998). Sea fish culture. C.U. Fisheries Faculty, Adana, P. 225 (Tr).

Tuzen, M. (2003). Determination of heavy metals in fish samples of the Mid Dam Lakee Black Sea (Turkey) by graphite furnace atomic absorption spectrometry. Food Chemistry, 80: $119-123$.

Veena, B.; Radhakrishanan, C.K. and Chacko, J. (1997). Heavy metal induced biochemical effects in an estuarine teleost. Indian J. Marine Sci., 26 : 74-78.

Wang, M.K. (1993). The effects of shrot-term acute cadmium exposure on Blue tilapia, (Oreochromis aureus). Environ. Biol. Fishes, 37:67-74.

Waqar, A. (2006). Levels of selected heavy metals in Tuna fish. Arab J. Sci. and Engineering, 1A (31): 89-92.

Weil, C.S. (1952). Tables for convenient calculation of median effective dose (LD50 or ED50) and instructions in their use. Biometriecs, 249-263. 


\title{
Effect of some heavy metals on physiological and chemical parameters in Nile tilapia (Oreochromis niloticus L.)
}

\author{
تأثير بعض العناصر الثقيلة على القياسات الفسيولوجية والكيميائية فى أسماك البلطى النيلى
}

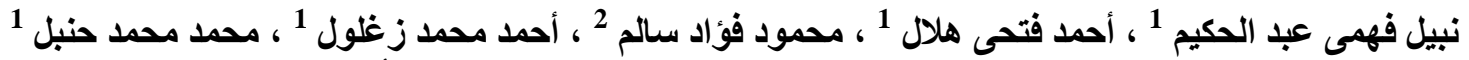

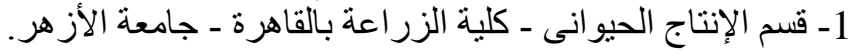

2- وحدة بحوث الثروة السمكية بسخا - كفر الثيخ التابعة للمعمل المركزى لبحوث الثرانيخ الثروة السمكية بالعباسة ـ الثرقية.

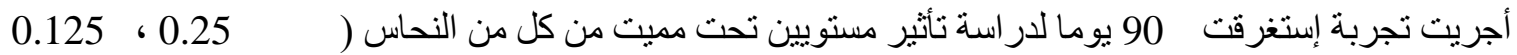

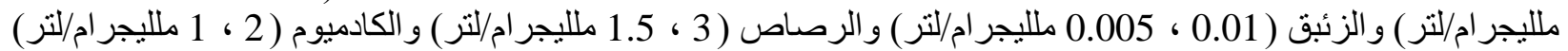

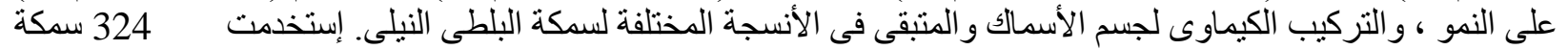

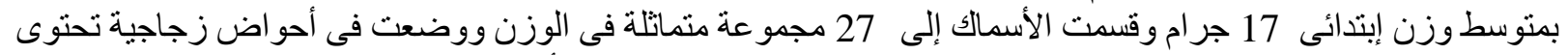

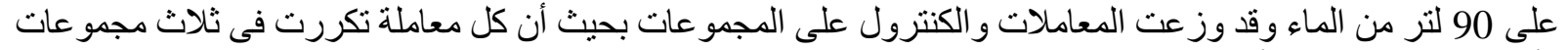

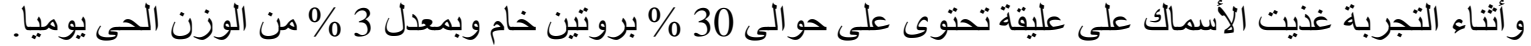

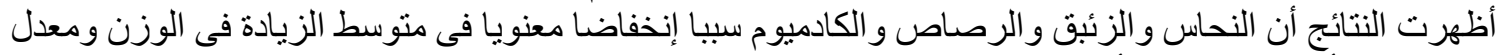

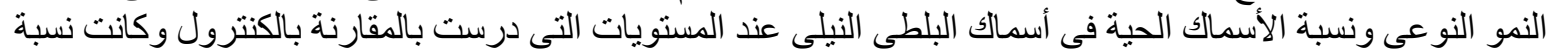

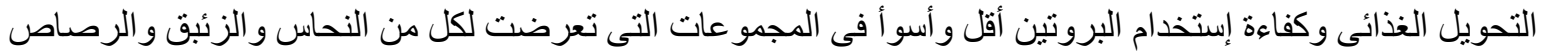

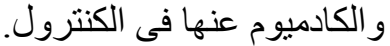

سبب النحاس و الزئبق و الرصاص الرئر و الكادميوم إنخفاضا في نسبة البروتين الخام فى جسم الأسماك. بينما زادت نسبة

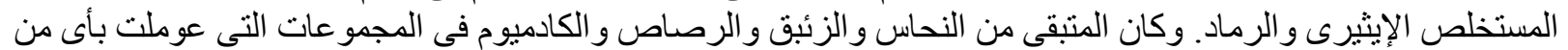

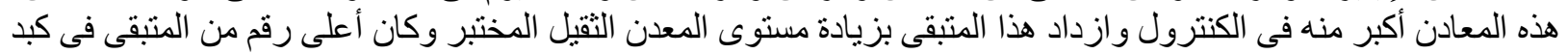

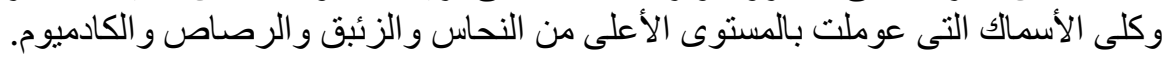

